\title{
Study on Cadmium Resistant-Bacteria Isolated from Hospital Wastewaters
}

\author{
Benmalek Yamina ${ }^{1}$, Benayad Tahar ${ }^{1}$, Madour Lila ${ }^{1}$, Hacene Hocine ${ }^{1}$, Fardeau Marie Laure ${ }^{2 *}$ \\ ${ }^{1}$ Laboratoire de Microbiologie, Département de BCM, Faculté des sciences biologiques, Université des Sciences \\ et de Technologie Houari Boumediene, Alger, Algerie \\ ${ }^{2}$ Laboratoire de Microbiologie IRD, Aix-Marseille Université, Université du Sud Toulon-Var, CNRS/INSU, IRD, \\ Marseille, France \\ Email: ${ }^{*}$ marie-laure.fardeau@univ-amu.fr
}

Received 8 May 2014; revised 18 June 2014; accepted 13 July 2014

Copyright @ 2014 by authors and Scientific Research Publishing Inc.

This work is licensed under the Creative Commons Attribution International License (CC BY).

http://creativecommons.org/licenses/by/4.0/

(c) $\underset{\mathrm{EY}}{\mathbf{2}}$ Open Access

\begin{abstract}
In hospital, a variety of substances are in use for medical purposes as diagnostics and researches. Among them, heavy metals which are not biodegradable by chemical reactions have bioaccumulation properties. Cadmium is a toxic pollutant that enters hospital wastewaters by different ways. However, isolated bacteria from hospital effluents have high resistance to antimicrobial agents and therefore the ability to uptake cadmium and other metals. So, their use is recommended for wastewater bioremediation. In this study, twelve cadmium-resistant bacteria were isolated from hospital wastewaters and identified. The cadmium-resistant isolates characterized include both Gram-negative [75\%] and Gram-positive [25\%]. The Minimum Inhibitory Concentration of hospital wastewaters isolates was determined in solid media and was ranged from 250 to 950 micrograms/milliliters. All the isolates showed co-resistance to zinc and mercury. They were also antibiotic resistant and tolerated up a significant concentration of $\mathrm{NaCl}$. The cadmium-resistant species Klebsiella pneumoniae and Pseudomonas aeruginosa were the most resistant to cadmium. The species Klebsiella pneumonia also resists to the highest concentrations of zinc and mercury. The results of toxicity tests on Vibrio fischeri, showed that the $\mathrm{DI}_{50}[15 \mathrm{~min}]$ as low as 0.07 carried away $\mathbf{5 0 \%}$ luminescence inhibition.
\end{abstract}

Keywords

Antibiotics, Cadmium-Resistant Bacteria, Hospital Wastewaters

\section{Introduction}

Health establishments produce large amounts of effluents. They are composed of wastewater related to domestic

${ }^{*}$ Corresponding author.

How to cite this paper: Yamina, B., Tahar, B., Lila, M., Hocine, H. and Laure, F.M. (2014) Study on Cadmium Resistant-Bacteria Isolated from Hospital Wastewaters. Advances in Bioscience and Biotechnology, 5, 718-726.

http://dx.doi.org/10.4236/abb.2014.58085 
and urban activities, and those specific to hospital practices [1]. Hospital wastewaters contain a variety of toxic and persistent substances such as drug residues, chemical reagents, and disinfectants for medical purposes in a wide range of concentrations, detergents, solvents, revealing and radiographic fixing and radionuclides. Most molecules belong to the so called emerging contaminants [2]. Eventually, they contain a number of fecal and pathogens microorganisms for which most of them are multiresistant [3]. Hospital effluents are also considerable source of various micropollutants such as pharmaceuticals which have a hard effect on all organisms in environment [4]. Hospital effluents are often considered to be of the same pollutant nature as domestic wastewaters, but characterized by a lower level of pollution compared to them. It also has been reported that hospital wastewater contain a great variety of toxic or persistent molecules such as heavy metals [2]. It also has been reported that the concentrations of metal ions are of the same order of magnitude in domestic wastewater except for platinium, mercury and gadolinium which are in higher concentrations in hospital effluent. Among these heavy metals, cadmium, lead and mercury are the most dangerous and potentially toxic to living organisms, especially microorganisms. Cadmium is not only toxic but also characterized by high stability and bind to essential respiratory enzymes causing oxidative stress. Microbial populations present in hospital effluents contain microorganisms which have acquired a variety of mechanisms for resistance to drugs and toxic elements. Among the diverse biological processes, transportation across the cell membrane, biosorption to the cell walls and entrapment in extracellular capsules, precipitation and complexation and oxidation-reduction [5]. The detoxification mechanisms may be directed against one metal or a group of chemically related metals and drugs. Furthermore, the detoxification mechanisms may vary depending on the type of microorganism. However, antibiotic transport by these systems, combined with other resistance-mechanisms is responsible for the selection of strains highly resistant to multiple antibiotics and other antimicrobial agents [6]. Most microorganisms are known to have specific genes for resistance to toxic ions of heavy metals and antibiotics. Mostly, the resistance genes are found on mobile elements or on chromosomes [7] [8].

The purpose of this study is isolation and identification of cadmium-resistant bacteria in hospital wastewaters, determination of MIC ranges of resistance by those indigenous bacteria and studying the co-resistance of the isolates to zinc and mercury and the antibiotics resistance. Evenly, the paper studies the tolerance of cadmium-resistant bacteria to different concentrations of $\mathrm{NaCl}$ and measures the toxicity of hospital wastewaters by a bioassay using the bioluminescent bacterial strain $V$. fischeri NRRL.B-11177.

\section{Materials and Methods}

Hospital presentation: the hospital El Kettar is located in BAB EL OUED city in Algiers, Algeria. The care activities of this hospital are directed towards infectious diseases caused by bacteria or virus such as tuberculosis, meningitis, hepatitis and AIDS. Effluent hospital discharges directly into the sea without any treatment.

Hospital effluents sampling: samples were taken from the central gaze of the hospital from the surface on March 2013 at $9 \mathrm{~h} 30 \mathrm{~min}$ in the morning. To achieve the different analysis, five liters of wastewaters were collected and transported immediately to the laboratories.

Physicochemical analysis: hospital effluents collected in plastic bottles were transferred to SEAAL Laboratory in KOUBA city, Algiers-Algeria, to achieve the following analysis: $\mathrm{pH}, \mathrm{BOD}_{5}$, COD, electrical conductivity, TSS, phosphate, total Phosphorus, nitrates, nitrites, ammonium, total nitrogen and orthophosphate. The concentration of cadmium was measured by atomic absorption spectrometry [Philips, PU 9100X]. Before analysis of metal concentration, hospital wastewater was filtered through 0.45 micrometer pore size hydrophilic membranes filters [Sartorious Millipore, Germany]. The temperature was measured in situ.

Bioassay test: the bioluminescent analysis is one of the most promising express methods for biologically monitoring the environment because the luminescent system is highly sensitive to even micro-quantities of pollutants [9]. The bioassay was carried out with a Toxtracer system [SKALAR, 2000], following the standard procedure of the European Standard NF EN ISO 11348-3 [AFNOR, 1998], using the Gram-negative marine bioluminescent bacteria of the species Vibrio fischeri NRRL.B-11177. To prevent the interferences of TSS on the bacteria luminescence, hospital wastewaters were filtered using 0.45 micrometer pore size membrane. The lyophilized culture of $V$. fischeri was reconstitute in HEPES [HEPES: 4-[2-hydroxyethyl]-1 piperazineethanesulfonic acid] and cultured on solid and liquid media. Seven consecutive dilutions of hospital effluents were prepared $[0.5,0.25,0.125,0.062,0.031,0.015,0.007]$ and tested for their toxic effect. To prepare the first dilution [0.5], 5 milliliters of liquid effluents were introduced into 5 milliliters of sterile physiological solution 
[NaCl9\%o]. To obtain the second dilution [0.25], 5 milliliters of the first dilution were transferred into 5 milliliters of sterile physiological solution, etc. The dilution factor is 1: 2 . The control used in this bioassay contains 500 microliters HEPES/500 microliters SCS [SCS: standard cellular suspension]. Inhibition of bioluminescence was measured at a wave length of $490 \mathrm{~nm}$ with reading after 15 min of incubation at $15^{\circ} \mathrm{C} \pm 1^{\circ} \mathrm{C}$.

Preliminary screening of cadmium-resistant bacteria: the screening of cadmium-resistant bacteria was carried out from hospital wastewaters using nutrient-agar [Difco] as basal medium [10]. The cadmium solution was prepared in sterile distilled water and sterilized by autoclaving at $120^{\circ} \mathrm{C}$ for $20 \mathrm{~min} .100 \mathrm{micrograms} / \mathrm{milliliters}$ of cadmium were taken from the metal solution and incorporated in the medium. The method used was based on serial dilution technical [11]. 1 milliliter of hospital wastewaters was added to a tube containing 9 milliliters of sterile physiological water and well mixed $\left[10^{-1}\right]$. To prepare the second dilution, one milliliter of the first one was transferred to another tube $\left[10^{-2}\right]$. Dilution was repeated till $10^{-3} .0 .1$ milliliter of each dilution was spread in mass of nutrient-agar and Petri plates were incubated at $30^{\circ} \mathrm{C}$ for $24 \mathrm{~h}$ to $48 \mathrm{~h}$.

Isolation procedure and characterization of cadmium-resistant bacteria: the different distinct colonies obtained on nutrient agar were sub-cultured on the same media for purification. The pure cultures were characterized and identified on the basis of colonies and cells morphology, Gram-stain, study of some physiological and biochemical characteristics such as respiratory type, catalase, oxydase and nitrate reductase tests, degradation of glucose, lactose, gas and $\mathrm{H}_{2} \mathrm{~S}$ production on Kligler and Hadjna medium [KIA]. The tests were used according to Bergey's Manual of Systematic Bacteriology. Api 20E and api 50H systems were also used to identify the cadmium-resistant bacteria. The most resistant bacteria were also identified by the sequencage of the $\mathrm{RNA}_{\mathrm{r}} 16 \mathrm{~S}$ in the laboratories IRD [France], and GATC [Germany].

Determination of Minimum Inhibitory Concentration [MIC]: after the isolation of the cadmium-resistant bacteria, the MIC of cadmium was determined by gradually increasing the concentration of the heavy metal: 50 micrograms/milliliters each time on nutrient-agar plate. The initial concentration used for this study was 100 micrograms/milliliters. Each plate was spread with overnight culture of the bacterial strains and Petri plates were incubated at $30^{\circ} \mathrm{C}$. The reading was taken every day for a period of 10 days. The culture growing on the last concentration was transferred to the higher concentration by streaking on a new plate. MIC was noted when the strains failed to grow on plates even after 10 days.

Co-resistance to zinc and mercury chloride: all the isolates cadmium-resistant were tested for their ability to resist to zinc and mercury. A measure of 100 micrograms/milliliters and 10 micrograms/milliliters were used as initial concentrations which were gradually increased of 50 micrograms/millilitres each time for the first metal and 10 micrograms/millilitres for the second until MIC was obtained.

Study of sodium chloride tolerance: a series of Petri dishes containing nutrient agar with increasing concentrations of $\mathrm{NaCl}$ were prepared. Each plate was spread with overnight culture of the bacterial strains and Petri plates were incubated at $30^{\circ} \mathrm{C}$ for $24 \mathrm{~h}$ to $48 \mathrm{~h}$. Strains were noted sensitive when they failed to grow on plates.

Determination of antibiotic sensitivity: as heavy metal-resistance is linked with antibiotic-resistance, the isolates were tested for their resistance to five antibiotics using Mueller-Hinton agar and the disc diffusion method. Standard antibiotic-impregnated discs were placed on freshly prepared lawns of each isolate on Mueller-Hinton plates. After $24 \mathrm{~h}$ to $48 \mathrm{~h}$ of incubation at $30^{\circ} \mathrm{C}$, the diameter of the inhibition zones was measured and the strains were classified as resistant [R], intermediate [I] and susceptible [S] following the standard antibiotic disk chart. Discs containing the following antibiotics were tested: oxacillin [5 micrograms], kanamycin [30 UI], cefotaxim [30 micrograms], sulfonamids [20 micrograms], nalidixic acid [30 micrograms].

\section{Results and Discussion}

\subsection{Physicochemical Analysis}

Analysis of wastewaters collected from El Kettar hospital revealed that cadmium concentration of the sample from which the bacteria were isolated was 0.126 micrograms/liter. The value of temperature measured in situ was $19^{\circ} \mathrm{C}$. The results obtained for the others parameters [Table 1], revealed that the electrical conductivity value was very important [2698 uS/cm], following by the COD [1117.44 micrograms/liter] and the BOD $_{5}[752.00$ micrograms/liters. In order to know if the hospital wastewaters have characteristics of domestic wastewaters, $\mathrm{COD} / \mathrm{BOD}_{5}$ ratio was calculated, and the result was 1.46 . Biochemical Oxygen Demand $\mathrm{BOD}_{5}$ is a measure of the amount of oxygen that bacteria will consume while decomposing organic matter under aerobic conditions. If effluent with high $\mathrm{BOD}_{5}$ levels is discharged into the sea it will accelerate bacterial growth in these aquatic en- 
Table 1. Values of physicochemical parameters of hospital wastewaters.

\begin{tabular}{ccc}
\hline Parameters & Units & Values \\
\hline PH & $\mathrm{U}$ & 07.73 \\
BOD & $\mathrm{mg} / \mathrm{L}$ & 752.00 \\
COD & $\mathrm{mg} / \mathrm{L}$ & 1117.44 \\
TSS & $\mathrm{mg} / \mathrm{L}$ & 952.00 \\
Conductivity & $\mathrm{uS} / \mathrm{cm}$ & 2698.00 \\
Orthophosphate & $\mathrm{mg} / \mathrm{L}$ & 27.50 \\
Nitrates & $\mathrm{mg} / \mathrm{L}$ & 01.902 \\
Nitrites & $\mathrm{mg} / \mathrm{L}$ & 00.33 \\
Total nitrogen & $\mathrm{mg} / \mathrm{L}$ & 288.00 \\
Ammonium ions & $\mathrm{mg} / \mathrm{L}$ & 124.40 \\
Total phosphorus & $\mathrm{mg} / \mathrm{L}$ & 21.20 \\
\hline
\end{tabular}

vironments and consume the oxygen levels in the littoral. The oxygen may decrease to levels that are lethal for most fishes and most of aquatic life.

\subsection{Bioassay Test}

Results obtained from the bioassay tests were expressed in percentage of sample dilutions and luminescence inhibition and showed that the bioluminescence of the luminescent marine bacteria used in this study decreased with increasing the dilution sample. Effect of hospital wastewaters on $V$. fischeri is very important after 15 min of exposure with $\mathrm{DI}_{50}=0.07, \mathrm{r}=0.98, \mathrm{n}=6$ and the bioluminescence inhibition reached to $50 \%$. The $\mathrm{DI}_{50}$ is the hospital wastewaters dilution which inhibited $50 \%$ of the bioluminescence of $V$. fischeri and " $n$ ", the number of points as depicted in the Figure 1.

\subsection{Isolation and Characterization of Hospital Wastewaters Bacteria}

A total of twenty two cadmium-resistant bacteria were isolated from wastewaters of the El Kettar hospital. Based on their high level metal-resistance, twelve isolates were selected and studied extensively. The heterotrophic cadmium-resistant strains characterized and identified by api $20 \mathrm{E}$, api $50 \mathrm{H}$ and molecular methods, showed wide varieties of species including Gram-negative [75\%] and Gram-positive [25\%]. The hospital wastewaters bacteria were: Pseudomonas aeruginosa [99\%], Pseudomonas putida [99\%], Morganella morganii [98\%], Morganella morganii [99\%], Klebsiella pneumoniae [99.9\%], Pontoea sp [98.2\%], Mannheimia haemolytica [97.2\%], Alcaligenes feacalis [98\%], Providencia rettgeri [98\%], Microbacterium hydrocarbonoxydans [99\%], Microbacterium paraoxydans [99\%] and Microbacterium lacticum [99\%]. All the Gram-positive isolates were members of the genus Microbacterium; they exhibited yellow-pigmented rods and were usually isolated from human clinical specimens. The Gram-negative bacterium Mannheimia haemolytica was a commensal of cattle, sheep, and other ruminants but also causes bovine and ovine pneumonic pasteurellosis. The cadmium-resistant bacteria characterized pertain to five different families and three bacterial classes. Cadmium shows toxic effects on a wide range of microorganisms and the resulting chronic metal stress decreases the bacterial number, diversity and activity. Equally, it has been reported in field studies that cadmium was responsible for changes in species composition in microbial populations.

\subsection{Determination of Minimum Inhibitory Concentration [MIC]}

Hospital wastewaters isolates showed high resistance for their relative heavy metal with MIC ranging from 250 to 950 micrograms/milliliters. The species Klebsiella pneumoniae and Pseudomonas aeruginosa were the most resistant to cadmium with MIC values of the order of 950 micrograms/milliliters. However, the species Providencia rettgeri, Morganella morganii and Pseudomonas putida were less resistant with MIC values 250 micrograms/milliliters and 300 micrograms/milliliters respectively [Table 2].

\subsection{Co-Resistance to Other Heavy Metals and Sodium Chloride Tolerance}

All the bacteria identified were tested for their co-resistance to zinc and mercury. Eventually, their ability to 


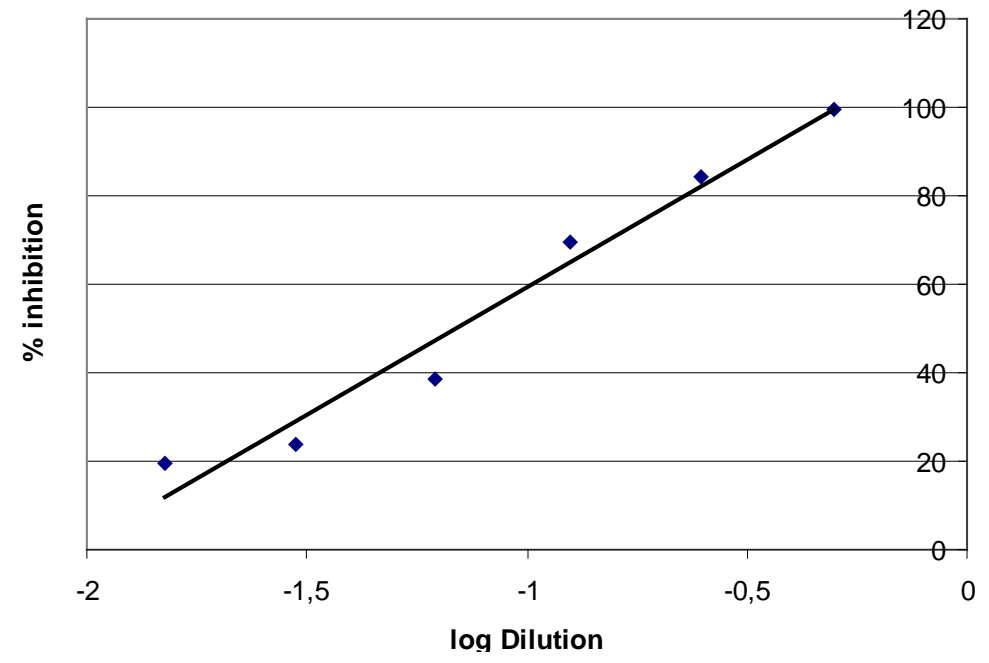

Figure 1. Effect of hospital wastewaters on the bioluminescence of $V$. fischeri NRRL. B-11177.

Table 2. Cadmium-resistant bacteria identified and MIC values.

\begin{tabular}{ccc}
\hline Wastewater bacteria & Similarity rate & MIC \\
\hline Pseudomonas aeruginosa & {$[99 \%]$} & $950 \mu \mathrm{g} / \mathrm{ml}$ \\
Pseudomonas putida & {$[99 \%]$} & $300 \mu \mathrm{g} / \mathrm{ml}$ \\
Morganella morganii & {$[98 \%]$} & $250 \mu \mathrm{g} / \mathrm{ml}$ \\
Morganella morganii & {$[99 \%]$} & $700 \mu \mathrm{g} / \mathrm{ml}$ \\
Klebsiella pneumoniae & {$[99.6 \%]$} & $950 \mu \mathrm{g} / \mathrm{ml}$ \\
Pontoea sp. & {$[98.2 \%]$} & $700 \mu \mathrm{g} / \mathrm{ml}$ \\
Mannheimia haemolytica & {$[97.2 \%]$} & $400 \mu \mathrm{g} / \mathrm{ml}$ \\
Alcaligenes feacalis & {$[98 \%]$} & $600 \mu \mathrm{g} / \mathrm{ml}$ \\
Providencia rettgeri & {$[98 \%]$} & $250 \mu \mathrm{g} / \mathrm{ml}$ \\
Microbacterium hydrocarbonoxydans & {$[99 \%]$} & $500 \mu \mathrm{g} / \mathrm{ml}$ \\
Microbacterium paraoxydans & {$[99 \%]$} & $850 \mu \mathrm{g} / \mathrm{ml}$ \\
Microbacterium lacticum & {$[99 \%]$} & $700 \mu \mathrm{g} / \mathrm{ml}$ \\
\hline
\end{tabular}

resist to salt stress was studied. The results obtained, summarized in Table 3, indicated that the MIC determined for zinc is very high and ranges from $950 \mu \mathrm{g} / \mathrm{ml}$ to $2000 \mu \mathrm{g} / \mathrm{ml}$. The species Klebsiella pneumonia, Providencia rettgeri and Alcaligenes feacalis, were the most resistant with MICs ranging from $1850 \mu \mathrm{g} / \mathrm{ml}$ to $2000 \mu \mathrm{g} / \mathrm{ml}$. The most sensitive strain was Pontoea $s p$ with950 $\mu \mathrm{g} / \mathrm{ml}$. For mercury, it was very important to note that the MIC was also considerable except for the species Pontoea sp. with a value of10 $\mu \mathrm{g} / \mathrm{ml}$. The most mercury-resistant species were Klebsiella pneumonia [90 $\mathrm{gg} / \mathrm{ml}$ ] following by Pseudomonas putida, and Morganella morganii with $80 \mu \mathrm{g} / \mathrm{ml}$. Hospital wastewaters bacteria were able to grow in presence of high concentrations of $\mathrm{NaCl}$. As shown in the Table 3, the concentrations were about 20 grams/liters to 80 grams/litres. The species Providencia rettgeri was considered as the most tolerant to sodium chloride with 80 grams/liters. However, the species Morganella morganii, Pontoea sp and Mannheimia haemolytica support only 10 grams/liters. The elevated rate of resistance to metals reflects an adaptive response to the presence of toxic elements in hospital wastewaters.

\subsection{Determination of Antibiotic Sensitivity}

Results listed in Table 4, revealed that hospital wastewater bacteria were resistant also to the different drugs tested. Meanwhile, the species Morganella morganii, Klebsiella pneumonia, Alcaligenes feacalis, Providencia rettgeri, Microbacterium hydrocarbonoxydans, Microbacterium paraoxydans and Microbacterium lacticum were resistant to all the antibiotics studied. The isolate Mannheimia haemolytica was intermediate resistant to 
Table 3. Values of heavy metal co resistance and $\mathrm{NaCl}$ tolerance of hospital wastewater bacteria.

\begin{tabular}{cccc}
\hline Cd $^{2+}$-resistant isolates & Zinc [MIC] & Mercury [MIC] & [NaCl] \\
\hline Pseudomonas aerpginosa [99\%] & $1150 \mu \mathrm{g} / \mathrm{ml}$ & $20 \mu \mathrm{g} / \mathrm{ml}$ & $50 \mathrm{~g} / \mathrm{L}$ \\
Pseudomonas putida [99\%] & $1100 \mu \mathrm{g} / \mathrm{ml}$ & $80 \mu \mathrm{g} / \mathrm{ml}$ & $30 \mathrm{~g} / \mathrm{L}$ \\
Morganella morganii [98\%] & $1000 \mu \mathrm{g} / \mathrm{ml}$ & $30 \mu \mathrm{g} / \mathrm{ml}$ & $10 \mathrm{~g} / \mathrm{L}$ \\
Morganella morganii [99\%] & $1250 \mu \mathrm{g} / \mathrm{ml}$ & $80 \mu \mathrm{g} / \mathrm{ml}$ & $30 \mathrm{~g} / \mathrm{L}$ \\
Klebsiella pneumoniae [99.6\%] & $2000 \mu \mathrm{g} / \mathrm{ml}$ & $90 \mu \mathrm{g} / \mathrm{ml}$ & $60 \mathrm{~g} / \mathrm{L}$ \\
Pontoea sp. [98.2\%] & $950 \mu \mathrm{g} / \mathrm{ml}$ & $10 \mu \mathrm{g} / \mathrm{ml}$ & $10 \mathrm{~g} / \mathrm{L}$ \\
Mannheimia haemolytica [97.2\%] & $1300 \mu \mathrm{g} / \mathrm{ml}$ & $20 \mu \mathrm{g} / \mathrm{ml}$ & $60 \mathrm{~g} / \mathrm{L}$ \\
Alcaligenes feacalis [98\%] & $1850 \mu \mathrm{g} / \mathrm{ml}$ & $40 \mu \mathrm{g} / \mathrm{ml}$ & $80 \mathrm{~g} / \mathrm{L}$ \\
Providencia rettgeri [98\%] & $2000 \mu \mathrm{g} / \mathrm{ml}$ & $40 \mu \mathrm{g} / \mathrm{ml}$ & $30 \mathrm{~g} / \mathrm{L}$ \\
[Microbacterium] 1500 $\mu$ g/ml hydrocarbonoxydans [99\%] & $30 \mu \mathrm{g} / \mathrm{ml}$ & $20 \mu \mathrm{g} / \mathrm{ml}$ & $60 \mathrm{~g} / \mathrm{L}$ \\
Microbacterium paraoxydans [99\%] & $1250 \mu \mathrm{g} / \mathrm{ml}$ & $20 \mu \mathrm{g} / \mathrm{ml}$ & $70 \mathrm{~g} / \mathrm{L}$ \\
Microbacterium lacticum [99\%] & $1050 \mu \mathrm{g} / \mathrm{ml}$ & &
\end{tabular}

Table 4. Results of antibiotics sensitivity of hospital wastewater bacteria.

\begin{tabular}{|c|c|}
\hline $\mathrm{Cd}^{2+}$-resistant isolates & Antibiotic resistant \\
\hline Pseudomonas aeruginosa [99\%] & $\mathrm{K}[\mathrm{R}], \mathrm{OX}[\mathrm{R}], \mathrm{NA}[\mathrm{R}], \mathrm{SS}[\mathrm{R}], \mathrm{CTX}[\mathrm{S}]$ \\
\hline Pseudomonas putida [99\%] & $\mathrm{K}[\mathrm{R}], \mathrm{OX}[\mathrm{R}], \mathrm{NA}[\mathrm{Ri}], \mathrm{SS}[\mathrm{Ri}], \mathrm{CTX}[\mathrm{S}]$ \\
\hline Morganella morganii [98\%] & $\mathrm{K}[\mathrm{R}], \mathrm{OX}[\mathrm{R}], \mathrm{NA}[\mathrm{R}], \mathrm{SS}[\mathrm{R}], \mathrm{CTX}[\mathrm{S}]$ \\
\hline Morganella morganii [99\%] & $\mathrm{K}[\mathrm{R}], \mathrm{OX}[\mathrm{R}], \mathrm{NA}[\mathrm{R}], \mathrm{SS}[\mathrm{R}], \mathrm{CTX}[\mathrm{R}]$ \\
\hline Klebsiella pneumoniae [99.6\%] & $\mathrm{K}[\mathrm{R}], \mathrm{OX}[\mathrm{R}], \mathrm{NA}[\mathrm{R}], \mathrm{SS}[\mathrm{R}], \mathrm{CTX}[\mathrm{R}]$ \\
\hline Pontoea sp. [98.2\%] & $\mathrm{K}[\mathrm{R}], \mathrm{OX}[\mathrm{R}], \mathrm{NA}[\mathrm{R}], \mathrm{SS}[\mathrm{R}], \mathrm{CTX}[\mathrm{S}]$ \\
\hline Mannheimia haemolytica [97.2\%] & $\mathrm{K}[\mathrm{R}], \mathrm{OX}[\mathrm{R}], \mathrm{NA}[\mathrm{R}], \mathrm{SS}[\mathrm{R}], \mathrm{CTX}$ [Ri] \\
\hline Alcaligenes feacalis [98\%] & $\mathrm{K}[\mathrm{R}], \mathrm{OX}[\mathrm{R}], \mathrm{NA}[\mathrm{R}], \mathrm{SS}[\mathrm{R}], \mathrm{CTX}[\mathrm{R}]$ \\
\hline Providencia rettgeri [98\%] & $\mathrm{K}[\mathrm{R}], \mathrm{OX}[\mathrm{R}], \mathrm{NA}[\mathrm{R}], \mathrm{SS}[\mathrm{R}], \mathrm{CTX}[\mathrm{R}]$ \\
\hline Microbacterium hydrocarbonoxydans [99\%] & $\mathrm{K}[\mathrm{R}], \mathrm{OX}[\mathrm{R}], \mathrm{NA}[\mathrm{R}], \mathrm{SS}[\mathrm{R}], \mathrm{CTX}[\mathrm{R}]$ \\
\hline Microbacterium paraoxydans [99\%] & $\mathrm{K}[\mathrm{R}], \mathrm{OX}[\mathrm{R}], \mathrm{NA}[\mathrm{R}], \mathrm{SS}[\mathrm{R}], \mathrm{CTX}[\mathrm{R}]$ \\
\hline Microbacterium lacticum [99\%] & $\mathrm{K}[\mathrm{R}], \mathrm{OX}[\mathrm{R}], \mathrm{NA}[\mathrm{R}], \mathrm{SS}[\mathrm{R}], \mathrm{CTX}[\mathrm{R}]$ \\
\hline
\end{tabular}

$\mathrm{K}=$ kanamycin, $\mathrm{OX}$ = oxacillin, $\mathrm{NA}$ = nalidixic acid, $\mathrm{SS}$ = sulfonamids, $\mathrm{CTX}$ = cefotaxim, R: resistant, I: intermediate, $\mathrm{S}$ : sensitive.

CTX, when the species Pseudomonas aeruginosa, Pseudomonas putida, Morganella morganii and Pontoea sp were sensitive. The antimicrobial resistance observed seem to be the result of bacteria exposure to antimicrobial compounds in hospital wastewaters which lead to the selection of resistance factors. Eventually, it has been reported that an environment with multiple stresses [antibiotics, disinfectants, detergents, chemical reagents and heavy metals], would be more favorable for a bacterium to acquire resistance to all stresses.

Results cited above revealed high values of conductivity, COD and $\mathrm{BOD}_{5}$ which indicate the presence of a lot of substances and dangerous molecules in hospital wastewaters that can alter the organization of aquatic organisms. Moreover, the bioassay test confirms that by a $\mathrm{DI}_{50}$ as low as 0.07 has carried away $50 \%$ luminescence inhibition of $V$. fischeri NRRL.B-11177. Although, the toxic effect of hospital effluents could be related to a variety of organic or inorganic chemical substances such as pharmaceuticals, radionuclides, solvents, disinfectants for medical purposes as diagnostics, disinfections and research. After application, these substances and excreted non metabolized by the patients drugs, enter into the hospital wastewaters which generally reach as well as the urban wastewaters release source of many toxic molecules in the aquatic environment which was not without risk for aquatic life [12]. The mechanisms underlying the toxic effects of chemicals may involve interactions with cell surface receptors, disruption of cell membrane functions and chemical reactions with cellular components or inhibition/competition of enzyme systems [13]. Hospital wastewaters are also considered as an appropriate environment where the microorganisms shall easily develop resistance to antimicrobial agents.

In the current research, nine Gram-negative bacteria and three Gram-positive were identified. These results 
could be explain by the presence of an outer membrane and a negatively surface charge of LPS as compared with Gram-positive bacteria; for this, Gram-negative were less affected by cadmium and other antimicrobial agents [14]. In the present study high degree of cadmium, zinc and mercury resistance associated with multiple antibiotic resistances was detected in hospital wastewaters bacteria. It is very important to mention that many earlier studies observed that heavy metal resistant bacteria are also resistant to many antibiotics and other toxic chemicals by virtue of carrying plasmids and or transposons encoding genetically linked metal and antibiotic resistance [15]. Besides that, several studies presented evidence that in wastewaters habitats there is a high potential for horizontal gene transfer, mediated by plasmids and facilitated by integrons [16]. It has been reported that plasmids carrying resistance genes have been identified in pathogenic bacteria of the genus Escherichia, Salmonella, Shigella, Klebsiella, Aeromonas, and Pseudomonas. These plasmids carry determinants for resistance to heavy metals such as nickel, cadmium, cobalt, silver, mercury, lead and zinc and drugs of different groups [Tetracyclines, quinolones, aminoglycosides, sulfonamides, $\beta$-lactams and chemotherapeutics [7]. Likewise, most results obtained from study on many clinical and environmental isolates reveal also that heavy metal and antibiotic resistance were often closely associated [17]. Ceylan and Uğur [18], demonstrated that bacteria resistance to heavy metals and antibiotics by genes present on their plasmids suggests the exertion of selective pressure on such bacteria through contamination with antibiotics and heavy metals in their environment. Eventually, Shamim and Rehman [19], reported that bacteria isolated from wastewaters such as Klebsiella pneumoniae and Pseudomonas aeruginosa resist to higher concentration of cadmium, which is in agreement with our results. Generally, the bacterium survives in metal-contaminated environments because it possesses a variety of transition metal efflux systems. Though, the zinc and cadmium-resistance in bacteria is achieved through the two general efflux mechanisms mediated by a P-type ATPase efflux system and an RND-driven transporter system [20]. As a matter of fact, a P-type ATPase catalyzes the reactions by ATP hydrolysis forming a phosphorylated intermediate [5], whereas, the term RND belongs to a family of proteins involved in the heavy metal transport. The P-type ATPase efflux system transports zinc ions across the cytoplasmic membrane by the energy released from ATP hydrolysis. In contrast to P-type ATPase efflux system, the RND-driven-transporter system does not derive energy throughATP hydrolysis to transport zinc within the bacterial cells. As an alternative, it is powered by the proton gradient across the cell wall specifically in Gram-negative bacteria [21]. However, resistance to mercury has been reported in a wide range of bacterial genus particularly in Gram-negative bacteria such as Pseudomonas, Alcaligenes, E. coli and Klebsiella [22]. Mercury resistance in bacteria is due to the mer operons constituted by genes encoded the functional proteins for regulation $[\operatorname{merR}]$, transport $[\operatorname{mer} T, \operatorname{mer} P]$ and reduction [merA]. It has a broad spectrum mercury resistance and found in Gram-negative bacteria and Gram-positive bacteria [23]. It has been reported that $\mathrm{Hg}$ resistance genes are inducible and their horizontal spread between bacteria is mediated by plasmids and other mobile elements such as integrons. These elements encode also resistance to different antibiotics [22]. Moreover, the bacterial cell resists to high concentrations of $\mathrm{NaCl}$ by developing various mechanisms of adaptation such as accumulation and production of halocines [24]. Based on their important potential, the use of metal-resistant bacteria in the treatment of heavy metal contaminated wastewaters has become more important and many efforts have been devoted to the isolation of heavy metal-resistant microorganisms during the last years.

\section{Conclusion}

The wastewaters of El Kettar hospital discharge directly into the sea. The physicochemical analysis of hospital wastewaters revealed that the electrical conductivity value was very important following by the COD and the $\mathrm{BOD}_{5}$. The hospital wastewaters have carried away $50 \%$ luminescence inhibition of $V$. fischeri at a $\mathrm{DI}_{50}$ as low as 0.07 after 15 min of exposure. The cadmium-resistant bacteria isolated from hospital effluent and characterized, revealed the existence of wide variety of microbial species distributed in five families and three bacterial classes at different ratio. Among the cadmium-resistant isolates, the species Klebsiella pneumoniae, was the most resistant to zinc and mercury. Bacteria of Hospital wastewaters were able also to grow in presence of high concentrations of $\mathrm{NaCl}$ and the species Providencia rettgeri tolerated up 80 grams/liters of $\mathrm{NaCl}$. Seven strains were resistant to all the antibiotics tested, whether a rate of 53.84\%.

\section{Acknowledgements}

We are grateful to the Central Scientific Laboratory of Police and SEAAL Laboratory in KOUBA city, Al- 
giers-Algeria for helpful and technical assistance.

\section{References}

[1] Verlicchi, P., Galletti, A. and Masotti, L. (2010) Management of Hospital Wastewaters: The Case of the Effluent of a Large Hospital Situated in a Small Town. Water Science and Technology, 61, 2507-2519. http://dx.doi.org/10.2166/wst.2010.138

[2] Verlicchi, P., Galletti, A., Petrovic, M. and Barcelo, D. (2010) Hospital Effluents as a Source of Emerging Pollutants: An Overview of Micropollutants and Sustainable Treatment Options. Journal of Hydrology, 389, 416-428. http://dx.doi.org/10.1016/j.jhydrol.2010.06.005

[3] Passerat, J., Tamtam, F., Le Bot, B., Eurin, J., Chevreuil, M. and Servais, M. (2010) Rejets Hospitaliers D’Antibiotiques et de Bactéries Fécales Antibio-Résistantes dans les Rivières du Bassin de la Seine. European Journal of Water Quality, 41, 1-13.

[4] Kummerer, K. (2010) Pharmaceuticals in the Environment: Sources, Fate, Effects and Risks. Environmental Science and Pollution Research, 17, 519-521.

[5] Ahemad, A. and Mulugeta Kibret, M. (2013) Recent Trends in Microbial Biosorption of Heavy Metals: A Review. Biochemistry and Molecular Biology, 1, 19-26.

[6] Seeger, M.A., Diederichs, K., Eicher, T., Brandstätter, L., Schiefner, A., Verrey, F. and Pos, K.M. (2008) The AcrB Efflux Pump: Conformational Cycling and Peristalsis Lead to Multidrug Resistance. Current Drug Targets, 9, 729-749. http://dx.doi.org/10.2174/138945008785747789

[7] Stokes, H.W. and Gillings, M.R. (2011) Gene£ow, Mobile Genetic Elements and the Recruitment of Antibiotic Resistance Genes into Gram-Negative Pathogens. FEMS Microbiology Reviews, 35, 790-819. http://dx.doi.org/10.1111/j.1574-6976.2011.00273.x

[8] Hookoom, M. and Puchooa, D. (2013) Isolation and Identification of Heavy Metals Tolerant Bacteria from Industrial and Agricultural Areas in Mauritius. Current Research in Microbiology and Biotechnology, 1, 119-123.

[9] Medvedeva, S.E., Tyulkova, N.A., Alexander, M., Kuznetsov, A.M. and Rodicheva, E.K. (2009) Bioluminescent Bioassays Based on Luminous Bacteria. Journal of Siberian Federal University, 4, 418-452.

[10] Rani, J.M., Hemambika, F.B., Hemaprya, J. and Rajeshkannan, V. (2010) Comparative Assessment of Heavy Metal Removal by Immobilized and Dead Bacterial Cells: A Biosorption Approach. Global Journal Environmental Research, 4, 23-30.

[11] Shakibaie, M.R., Khosravan, A., Farahmand, A. and Zareh, S. (2009) Elimination of Copper and Zinc from Industrial Wastes by Mutated Bacteria. Journal of Kerman University of Medical Sciences, 16, 13-24.

[12] Rosal, R., Rodea-Palomares, I., Boltes, K., Fernández-Piñas, F., Leganés, F., Gonzalo, S. and Petre, A. (2010) Ecotoxicity Assessment of Lipid Regulators in Water and Biologically Treated Wastewater Using Three Aquatic Organisms. Environmental Science and Pollution Research, 17, 135-144. http://dx.doi.org/10.1007/s11356-009-0137-1

[13] Mariscal, A., Peinado, M.T., Carnero-Varo, M. and Fernandez-Crehuet, J. (2003) Influence of Organic Solvents on the Sensitivity of a Bioluminescence Toxicity Test with Vibrio harveyi. Chemosphere, 50, 349-354. http://dx.doi.org/10.1016/S0045-6535(02)00312-0

[14] Kafilzadeh, F., Moghtaderi, Y. and Jahromi, A.R. (2013) Isolation and Identification of Cadmium-Resistant Bacteria in Soltan Abad River Sediments and Determination of Tolerance of Bacteria through MIC and MBC. European Journal of Experimental Biology, 3, 268-273.

[15] Devika, L., Rajaram, R. and Mathivanan, K. (2013) Multiple Heavy Metal and Antibiotic Tolerance Bacteria Isolated from Equatorial Indian Ocean. International Journal of Microbiological Research, 4, 212-218.

[16] Novo, A., André, S., Viana, P., Nunes, O.C. and Manaia, C.M. (2013) Antibiotic Resistance, Antimicrobial Residues and Bacterial Community Composition in Urban Wastewater. Water Research, 47, 1875-1887. http://dx.doi.org/10.1016/j.watres.2013.01.010

[17] Jafari, E, Shakibaie, M.R. and Poormasoomi, L. (2013) Isolation of a Novel Plasmid from Hospital Isolate of Pseudomonas aeruginosa. Journal Clinical and Experimental Pathology, 3, 1-5.

[18] Ceylan, O. and Uğur, A. (2012) Bio-Monitoring of Heavy Metal Resistance in Pseudomonas and Pseudomonas Related Genus. Journal of Biological Environmental Science, 6, 233-242.

[19] Shamim, S. and Rehman, A. (2012) Cadmium Resistance and Accumulation Potential of Klebsiella pneumoniae Strain CBL-1 Isolated from Industrial Wastewater. Pakistan Journal Zoology, 44, 203-208.

[20] Scherer, J. and Nies, D.C. (2009) CzcP Is a Novel Efflux System Contributing to Transition Metal Resistance in Cupriavidus metallidurans CH34. Molecular Microbiology, 73, 601-621. 
http://dx.doi.org/10.1111/j.1365-2958.2009.06792.x

[21] Issazadeh, K., Jahanpour, N., Pourghorbanali, F., Raeisi, G. and Faekhondeh, J. (2013) Heavy Metals Resistance by Bacterial Strains. Annals of Biological Research, 4, 60-63.

[22] Mirzaei, N., Rastegari, H. and Kargar, M. (2013) Antibiotic Resistance Pattern among Gram-Negative Mercury Resistant Bacteria Isolated from Contaminated Environments. Jundishapur Journal of Microbiology, 6, 80-85.

[23] Zhang, W., Chen, L. and Liu, D. (2012) Characterization of a Marine-Isolated Mercury-Resistant Pseudomonas putida strain SP1 and Its Potential Application in Marine Mercury Reduction. Applied Microbiology and Biotechnology, 93, 1305-1314. http://dx.doi.org/10.1007/s00253-011-3454-5

[24] Price, L.B. and Shand, R.F. (2000) Halocin S8 a 36-Amino-Acid Microhalocin from the Haloarchaeal Strain S8a. Journal of Bacteriology, 182, 4951-4958. http://dx.doi.org/10.1128/JB.182.17.4951-4958.2000 
Scientific Research Publishing (SCIRP) is one of the largest Open Access journal publishers. It is currently publishing more than 200 open access, online, peer-reviewed journals covering a wide range of academic disciplines. SCIRP serves the worldwide academic communities and contributes to the progress and application of science with its publication.

Other selected journals from SCIRP are listed as below. Submit your manuscript to us via either submit@scirp.org or Online Submission Portal.
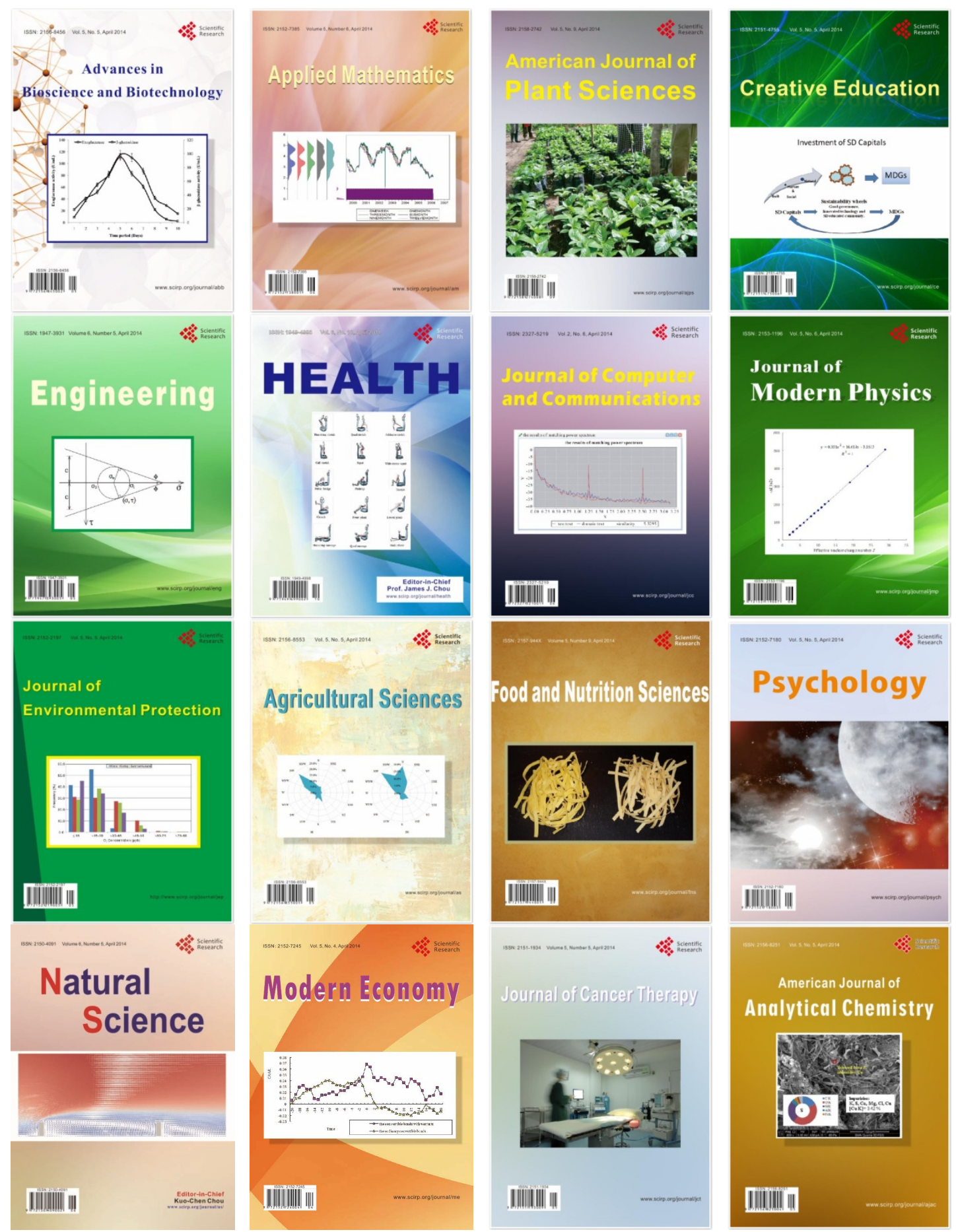